\title{
Overall quality of diabetes care in a defined geographic region: different sides of the same story
}

\author{
Rykel van Bruggen, Kees Gorter, Ronald Stolk, Peter Zuithoff, Rob Verhoeven and Guy Rutten
}

\begin{abstract}
\section{Background}

In diabetes care, knowledge about what is achievable in primary and secondary care is important. There is a need for an objective method to assess the quality of care in different settings. A quality-of-care summary score has been developed based on process and outcome measures. An adapted version of this score was used to evaluate diabetes management in different settings.
\end{abstract}

Aim

To evaluate the quality of diabetes management in primary and secondary care in a defined geographic region in the Netherlands, using a quality score.

\section{Design of study}

Cross-sectional study.

\section{Setting}

Thirty general practices in the Netherlands.

Method

A study of 2042 patients with type 2 diabetes (1640 primary care and 402 secondary care) was conducted. Quality of diabetes management was assessed by a score of process and outcome indicators (range 0-40).

Clustering at practice level and differences in patient characteristics (case mix) were taken into account.

\section{Results}

At the outpatient clinic, patients were younger (mean age 64.1 years, standard deviation $(\mathrm{SD})=12.5$ years, versus mean age 67.1 years, $S D=11.7, P<0.001$ ), had more diabetes-related complications (macrovascular: 39.7\% versus $24.3 \%, P<0.001$; and microvascular: $25.9 \%$ versus $7.3 \%, P<0.001$ ), and lower quality-of-life scores (EuroQol-5D: mean $=0.60, \mathrm{SD}=0.29$, versus mean $=$ $0.80, \mathrm{SD}=0.21, P<0.001)$. After adjusting for case mix and clustering, there was a weak association between the setting of treatment and haemoglobin A1c (primary care: mean $7.1 \%, \mathrm{SD}=1.1$, versus secondary care: mean $7.6 \%, \mathrm{SD}=1.2, P<0.016$ ), and between setting and systolic blood pressure (primary: mean $145.7 \mathrm{mmHg}$, SD $=19.2$, versus secondary care: $147.77 \mathrm{mmHg}$, SD 21.0, $P<0.035)$. Quality-of-care summary scores in primary and secondary care differed significantly, with a higher score in primary care (mean 19.6, SD = 8.5 versus, mean 18.1, SD $=8.7, P<0.01)$. However, after adjusting for case mix and clustering, this difference lost significance.

\section{Conclusion}

GPs and internists are treating different categories of patients with type 2 diabetes. However, overall quality of diabetes management in primary and secondary care is equal. There is much room for improvement. Future guidelines may differentiate between different categories of patients.

\section{Keywords}

case mix; hospital; medical staff, primary health care; quality of health care; type 2 diabetes mellitus.

\section{INTRODUCTION}

In the Netherlands approximately 600000 patients are known to have type 2 diabetes. ${ }^{1}$ Of these patients, $75 \%$ are primarily being treated in general practice. ${ }^{2}$ It has been emphasised that case mixes in primary and in secondary care are unequal, and that it is necessary to take these inequalities into account when comparing the outcome of care in different settings. ${ }^{3,4}$ In general, there is as much variation in outcomes within disciplines as between them. ${ }^{5}$

Diabetes care is shared care and, consequently, close cooperation between hospitals and GPs is essential. Given the necessity to collaborate, knowledge about what is achievable both in and outside the hospital is important, as this will influence the development and implementation of guidelines and the sharing of responsibilities. There is a need for an objective method to assess the quality of diabetes care, both in general practice and at outpatient clinics.

The Diabetes Quality Improvement Project has developed a comprehensive set of measures to assess quality of care accurately and reliably. Implementation of this set of measures is expected to bring quality improvement. ${ }^{6}$ Recently the Quality of Care and Outcomes in Type 2 Diabetes study group developed a quality-of-care summary score

R van Bruggen, GP; K Gorter, PhD, GP; P Zuithoff, MSc, statistician; G Rutten, professor, PhD, GP, Department of General Practice, Julius Centre for Health Sciences and Primary Care, University Medical Centre Utrecht, Utrecht. $\boldsymbol{R}$ Stolk, professor, $\mathrm{PhD}$, epidemiologist, Department of Epidemiology, University Medical Centre Groningen, Groningen. $\mathbf{R}$ Verhoeven, $P h D$, internist, Department of Internal Medicine, Gelre Hospital, Apeldoorn, the Netherlands.

Address for correspondence

Dr Rykel Adrianus van Bruggen, UMC Utrecht, Julius Centre, P.B. 85500, Stratenum 6.101, Utrecht, 3508 GA, the Netherlands. E-mail: j.a.r.vanbruggen@umcutrecht.nl

Submitted: 6 July 2007; Editor's response: 29 August 2007; final acceptance: 18 January 2008.

(c)British Journal of General Practice 2008; 58: 339-345.

DOI: 10.3399/bjgp08X280209 


\section{How this fits in}

There has been much debate about the quality of primary diabetes care.

Generally, the process of care tends to be better in a secondary care setting,

but differences in metabolic outcome between the primary and secondary care

setting are less clear. When using a multi-item quality score consisting of

process and outcome measures, the overall quality of diabetes care was equal

after correcting for the different distributions of patient characteristics (case mix)

as they occur in different health care settings. GPs and internists are treating

different categories of patients with type 2 diabetes. As total quality scores were

low, there is room for improvement. duration of diabetes, smoking habits, comorbidity, and the presence of macrovascular or microvascular complications were recorded. Standardised operating procedures were used to record body weight, height, and blood pressure. Fasting blood and urine samples were analysed at the local hospital laboratory. Haemoglobin A1c (HbA1c) was determined by the Variant IITM Turbo Haemoglobin Testing System (Bio-Rad). Plasma glucose, total cholesterol, high-density lipoprotein cholesterol, triglycerides, albumin/creatinine ratio, and microalbumen were determined with Architect $^{\circledast}$ ci8200SR (Abbott).

(QUED) based on readily available process and intermediate outcome indicators. ${ }^{7}$ Only indicators with a strong link with vascular complications were used. These measures were consistent with those adopted for the Diabetes Quality Improvement Project. After adjusting for case mix and clustering, a linear relationship between quality score and the incidence of cardiovascular events was found. Similar scores have not been used previously to evaluate the quality of diabetes management in a primary and secondary care setting simultaneously. The current study aims to fill this gap.

\section{METHOD}

In the Netherlands, everyone is registered with a general practice. All diabetes-related expenses are reimbursed by insurance companies. By law, all inhabitants are insured by one of these companies and when needed, subsidiaries are given to pay for insurance costs. A cluster randomised trial was performed comparing usual care with care according to locally-adapted shared care guidelines near Apeldoorn, a city with 150000 inhabitants. This paper describes the cross-sectional evaluation of diabetes management in primary and secondary care at the start of the intervention.

\section{Participants}

All primary care practices $(n=70)$ in the region, and all internists $(n=9)$ at the local hospital were asked to participate. All patients with diabetes $(n=3357)$ on the lists of the participating practices were eligible for this project, both those cared for by a GP and those treated at the outpatient clinic. In general practice, a computer search was performed to identify all patients known to have type 2 diabetes. Reasons for exclusion were the inability to complete a questionnaire, severe mental illness, unwillingness to attend the practice regularly, and a limited life expectancy.

\section{Measures}

General practice. At baseline, demographics,
Outpatient clinic. Specially trained nurses examined the records of all participants, extracted anthropometric data, and checked the histories of these patients for duration of diabetes, smoking habits, comorbidity, and the presence of macrovascular or microvascular complications. The records of the hospital laboratory were used to obtain the results of biochemical tests performed during the year preceding the start of the study.

Both settings. Health-related quality of life was estimated with the EuroQol-5D (range -0.59 to -1 , where 1 indicates perfect health) and the validated Dutch version of the disease-specific Diabetes Health Profile (range 0-100, where 100 represents no dysfunction). ${ }^{8,9}$ The overall health of the participants and their treatment satisfaction were measured with the visual analogue scale of the EuroQol-5D (range 0-100), and the treatment satisfaction questionnaire (range 0-36) respectively. ${ }^{10,11}$

The files of all 18 pharmacists and those of three GPs who had their own pharmacy were used to obtain a detailed medication profile of all patients using blood glucose lowering medication (Anatomical Therapeutic Chemical Classification System code A10), or those who had been diagnosed with diabetes by their GP. Subsequently, these profiles were matched with the research data.

Yearly measurement of $\mathrm{HbA1c}$, blood pressure, total cholesterol, albumin/creatinine ratio, and the prescription of angiotensin II (ATII) antagonists or angiotensin-converting enzyme (ACE) inhibitors in cases of microalbuminuria were identified as measures of the process of care. The percentages of patients with $\mathrm{HbA} 1 \mathrm{c}<8 \%$, systolic blood pressure $<140 \mathrm{mmHg}$, diastolic blood pressure $<8 \mathrm{mmHg}$, mean cholesterol $<6 \mathrm{mmol} / \mathrm{l}$ for nonsmokers or $<5 \mathrm{mmol} / \mathrm{l}$ for smokers, and diabetes treatment satisfaction were used as outcome measures.

Because local shared care guidelines differed 
from those used by the Italian Quality of Care and Outcomes in Type 2 Diabetes study group, ${ }^{3}$ slight modifications had to be made to the original quality summary score. The threshold for diastolic hypertension was set at $85 \mathrm{mmHg}$ instead of $90 \mathrm{mmHg}$. Total cholesterol was used as a substitute for low-density lipoprotein cholesterol. Instead of ACE inhibitors only, both ACE inhibitors and ATII antagonists were recommended in cases of microalbuminuria. The quality score was, like the original Italian score, designed prior to the data analysis and was not based on weights derived from regression models. The lowest score was assigned if a patient was not effectively treated despite elevated values. An intermediate score was credited if treatment goals were met, but measurement of a parameter was not performed within the last 12 months. Finally, the highest score was given if patients were treated in line with both process and outcome indicators (Table 1).

\section{Analysis}

The term 'case mix' is used to describe the distribution of patient characteristics in different healthcare settings. These characteristics are hypothesised to remain the same if a patient is assigned to another unit of care. ${ }^{12}$ As the distribution of such characteristics is not random, it may lead to case-mix bias. ${ }^{4}$ In this study, sex, age, duration of diabetes, macrovascular and microvascular complications, education, insulin use, and quality of life are considered case-mix variables. In the Quality of Care and Outcomes in
Type 2 Diabetes study, the risk of developing a cardiovascular event was $89 \%$ greater in patients with a score of $\leq 10$, and $43 \%$ higher in those with a score between 10-20, as compared to those with a score $>20$. The same cut-off points were used in the present study. To assess differences in baseline measurements between primary and secondary care, the Student's $t$ test, Mann-Whitney test, and $\chi^{2}$ test, were used where appropriate. A threshold value of at least one measurement per year was considered to be desirable, whatever the physicians' case mix.

Therefore, differences in the process of care between specialties were not adjusted for potential confounding by unequal case mixes. In the case of outcome measurements, multiple regression analysis was performed to account for confounding by case-mix differences between the primary and secondary care setting. Because multiple tests were involved, statistical significance was set at $P<0.01$. In both primary and secondary care, generalised estimating equations models were used to adjust for clustering at practice level. Analyses were carried out using the statistical package SPSS (version 12.0) for Windows. SAS software (version 8) was used for generalised estimating equations. Analyses were performed for both summary scores: the original QuED score, and the adapted version.

The percentage of missing values per variable ranged between $0 \%$ and $25.2 \%$; mean $17.6 \%$. Ignoring cases with a missing value may lead to biased results and loss of power. ${ }^{13,14}$ Therefore,

Table 1. Quality of diabetes management scoring system.

\begin{tabular}{|c|c|}
\hline Quality-of-care indicator & Score \\
\hline $\mathrm{HbA} 1 \mathrm{c} \geq 8.0 \%$ & 0 \\
\hline HbA1c $<8.0 \%$ but measurement less than 1 per year & 5 \\
\hline $\mathrm{HbA} 1 \mathrm{c}<8.0 \%$ and measurement at least 1 per year & 10 \\
\hline Blood pressure $>140 / 85 \mathrm{mmHg}$ & 0 \\
\hline Blood pressure values $<140 / 85 \mathrm{mmHg}$ but measurement less than 1 per year & 5 \\
\hline Blood pressure values $<140 / 85 \mathrm{mmHg}$ and measurement at least 1 per year & 10 \\
\hline Cholesterol $\geq 5 \mathrm{mmol} / \mathrm{l}$ (non-smokers without vascular complications) $\geq 6 \mathrm{mmol} / \mathrm{l}$ & 0 \\
\hline $\begin{array}{l}\text { Cholesterol }<5 \mathrm{mmol} / \mathrm{l} \text { (non-smokers without vascular complications) }<6 \mathrm{mmol} / \mathrm{l} \\
\text { but measurement less than } 1 \text { per year }\end{array}$ & 5 \\
\hline $\begin{array}{l}\text { Cholesterol }<5 \mathrm{mmol} / \mathrm{l} \text { (non-smokers without vascular complications) }<6 \mathrm{mmol} / \mathrm{l} \\
\text { and measurement at least } 1 \text { per year }\end{array}$ & 10 \\
\hline Not treated with ACE inhibitors despite the presence of microalbuminuria & 0 \\
\hline $\begin{array}{l}\text { Treated with ACE inhibitors or ATII antagonists in the presence of microalbuminuria, } \\
\text { or microalbuminuria absent but measurement less than } 1 \text { per year }\end{array}$ & 5 \\
\hline $\begin{array}{l}\text { Treated with ACE inhibitors or ATII antagonists in the presence of microalbuminuria, } \\
\text { or microalbuminuria absent but measurement at least } 1 \text { per year }\end{array}$ & 10 \\
\hline Score range & $0-40$ \\
\hline
\end{tabular}

HbA1c = haemoglobin A1c. ACE = angiotensin-converting enzyme. ATII = angiotensin II. 
Figure 1. Flow chart of participation

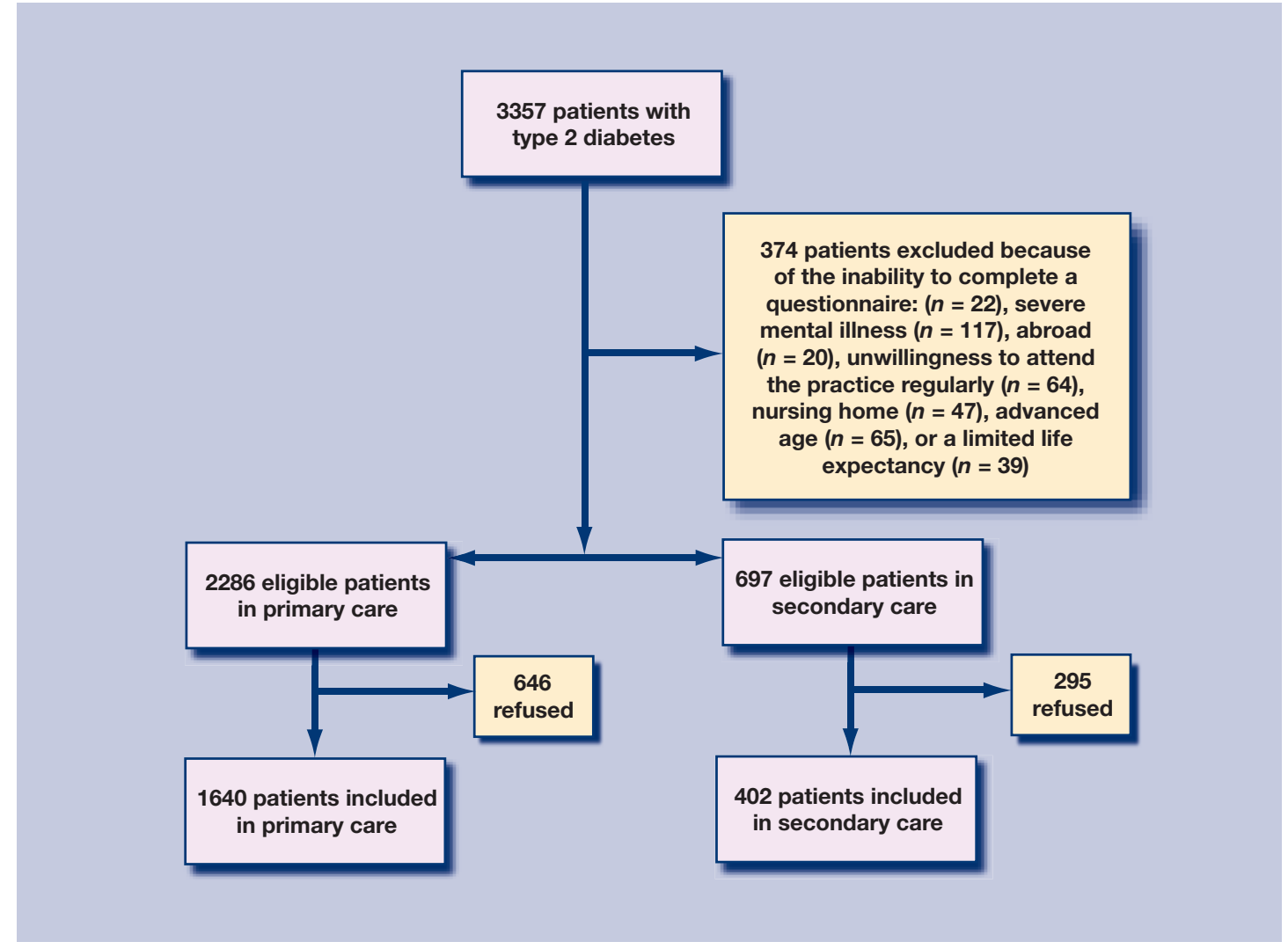

missing values were inputted using the regression method available in SPSS.

\section{RESULTS}

\section{Participants}

In total, 11 single-handed, 16 duo, and three group practices agreed to participate. Reasons for nonparticipation were a lack of time, a dislike of research projects, a lack of confidence in the outcome of the study, and the conviction that the practice performed well and did not need improvement. At the local hospital, all specialists agreed to participate. Overall, 2042 patients gave

Table 2. Case-mix variables in primary and secondary care.

\begin{tabular}{lccc} 
Case mix & Primary care & Secondary care & $P$-value \\
\hline Male, \% & 48.6 & 46.0 & 0.4 \\
\hline Age, years (SD) & $67.1(11.7)$ & $64.1(12.5)$ & $<0.001$ \\
\hline Primary school and technical school, \% & 57.9 & 54.0 & 0.2 \\
\hline Duration of diabetes, \% (SD) & $6.6(6.0)$ & $11.2(7.7)$ & $<0.001$ \\
\hline Macrovascular complications, \% & 34.3 & 39.7 & $<0.001$ \\
\hline Microvascular complications, \% & 7.3 & 25.9 & $<0.001$ \\
\hline Insulin use, \% & 5.7 & 65.8 & $<0.001$ \\
\hline EuroQol-5D (SD) & $0.80(0.21)$ & $0.70(0.29)$ & $<0.001$ \\
\hline EuroQol-VAS (SD) & $75.3(16.1)$ & $68.3(18.3)$ & $<0.001$ \\
\hline Diabetes Health Profile (SD) & $84.9(9.8)$ & $79.5(11.1)$ & $<0.001$ \\
\hline
\end{tabular}

their informed consent. Of these patients, 1640 were treated in primary care, and 402 were cared for at the outpatient clinic (Figure 1).

\section{Case mix}

Patients treated by GPs were older, had a shorter duration of diabetes, and fewer macrovascular and microvascular complications. Patients cared for at the outpatient clinic were more likely to be treated with insulin and had lower EuroQol-5D, visual analogue, and Diabetes Health Profile scores (Table 2).

\section{Process of care}

At the outpatient clinic, more patients were annually checked for their $\mathrm{HbA1c}$, and in cases of microalbuminuria, more patients were prescribed an ACE inhibitor or ATII antagonist. Measurement of microalbuminuria was performed more often in general practice. After correction for case mix and clustering, these differences became statistically non-significant (Table 3).

\section{Outcome of care}

HbA1c percentage in secondary care exceeded that in primary care. In both settings, the percentage of patients that achieved adequate blood pressure control was equal. However, more patients in secondary care attained adequate lipid 
Table 3. Process of care in primary and secondary care.

\begin{tabular}{|c|c|c|c|c|c|c|c|}
\hline \multirow[b]{2}{*}{ Process } & \multirow[b]{2}{*}{$\begin{array}{l}\text { Primary } \\
\text { care }\end{array}$} & \multirow[b]{2}{*}{$\begin{array}{l}\text { Secondary } \\
\text { care }\end{array}$} & \multicolumn{4}{|c|}{ Odds ratio $(95 \% \mathrm{Cl})$} & \multirow[b]{2}{*}{ ICC } \\
\hline & & & Unadjusted & $P$-value & $\begin{array}{l}\text { Full-model } \\
\text { adjustment }^{\mathrm{a}}\end{array}$ & $P$-value & \\
\hline $\begin{array}{l}\mathrm{HbA} 1 \mathrm{c} \text { measurement at least } \\
1 \text { per year }(\%)\end{array}$ & 83.8 & 90.5 & $\begin{array}{c}0.55 \\
(0.38 \text { to } 0.78)\end{array}$ & 0.001 & $\begin{array}{c}0.74 \\
(0.36 \text { to } 1.52)\end{array}$ & 0.416 & 0.055 \\
\hline $\begin{array}{l}\text { Blood pressure measurement at least } \\
1 \text { per year }(\%)\end{array}$ & 56.5 & 56.4 & $\begin{array}{c}0.99 \\
(0.80 \text { to } 1.24)\end{array}$ & 0.950 & $\begin{array}{c}1.10 \\
(0.63 \text { to } 1.92)\end{array}$ & 0.740 & 0.152 \\
\hline Lipid measurement at least 1 per year (\%) & 79.7 & 79.6 & $\begin{array}{c}1.001 \\
(0.76 \text { to } 1.31) \\
\end{array}$ & 0.992 & $\begin{array}{c}1.52 \\
(0.91 \text { to } 1.30) \\
\end{array}$ & 0.111 & 0.086 \\
\hline $\begin{array}{l}\text { Microalbuminuria measurement at least } \\
1 \text { per year (\%) }\end{array}$ & 45.2 & 34.7 & $\begin{array}{c}1.56 \\
(1.24 \text { to } 1.95) \\
\end{array}$ & $<0.001$ & $\begin{array}{c}1.39 \\
(0.74 \text { to } 2.61) \\
\end{array}$ & 0.310 & 0.186 \\
\hline $\begin{array}{l}\text { Prescription of ACE inhibitors or ATII antagonists } \\
\text { in the presence of microalbuminuria (\%) }\end{array}$ & 52.7 & 62.3 & $\begin{array}{c}1.48 \\
(1.08 \text { to } 2.03)\end{array}$ & 0.014 & $\begin{array}{c}1.24 \\
(0.77 \text { to } 2.01)\end{array}$ & 0.368 & 0.077 \\
\hline
\end{tabular}

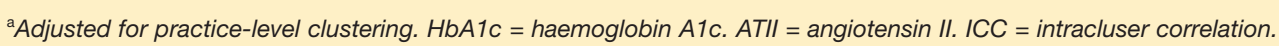

control. In general, patients were satisfied with their treatment. After correction for case mix and clustering, differences in mean $\mathrm{HbA} 1 \mathrm{c}$ percentage and the percentage of patients with $\mathrm{HbA} 1 \mathrm{c}<8 \%$ reached borderline significance, and weak evidence of an association between treatment setting and systolic blood pressure became apparent (Tables 4 and 5).

\section{Quality score}

The overall quality of diabetes care in primary and secondary care was different. The mean quality-ofcare summary score in general practice was higher (19.6, standard deviation $[S D]=8.5$ versus 18.1 , SD $=8.7$ points, difference $=1.41,95 \%$ confidence interval $[\mathrm{Cl}]=0.472$ to $2.352, P=0.003$ ), and fewer patients within primary care had a score $\leq 10$ points
(21.3 versus $26.5 \%$, odds ratio $[\mathrm{OR}]=0.74,95 \% \mathrm{Cl}$ $=0.573$ to $0.946, P=0.017$ ). However, after accounting for case mix and clustering, the difference in quality-of-care score lost significance (difference $=0.18,95 \% \mathrm{Cl}=-0.247$ to $0.612, P=$ 0.406). Only a weak association between treatment setting and the percentage of patients with fewer than 10 points remained $(\mathrm{OR}=0.66,95 \% \mathrm{Cl}=$ 0.465 to $0.949, P=0.024)$. A repeated analysis with the original model by the Quality of Care and Outcomes in Type 2 Diabetes study group produced similar results (data not shown).

\section{DISCUSSION}

\section{Summary of main findings}

At the outpatient clinic, patients were younger, had more macrovascular and microvascular

Table 4. Outcome of care in primary and secondary care.

\begin{tabular}{|c|c|c|c|c|c|c|c|c|c|}
\hline \multirow[b]{2}{*}{ Outcome } & \multirow[b]{2}{*}{$\begin{array}{l}\text { Primary } \\
\text { care }\end{array}$} & \multirow[b]{2}{*}{$\begin{array}{c}\text { Secondary } \\
\text { care }\end{array}$} & \multicolumn{6}{|c|}{ Difference (95\% Cl) } & \multirow[b]{2}{*}{ ICC } \\
\hline & & & Unadjusted & $P$-value & $\begin{array}{c}\text { Case-mix } \\
\text { adjustment }^{\mathrm{a}}\end{array}$ & $P$-value & $\begin{array}{l}\text { Full-model } \\
\text { adjustment }^{\text {b }}\end{array}$ & $P$-value & \\
\hline $\mathrm{HbA1c}$ \% (SD) & $7.1(1.1)$ & $7.6(1.2)$ & $\begin{array}{c}-0.51 \\
(-0.64 \text { to }-0.39)\end{array}$ & $<0.001$ & $\begin{array}{c}-0.27 \\
(-0.44 \text { to }-0.11)\end{array}$ & 0.001 & $\begin{array}{c}-0.28 \\
(-0.51 \text { to }-0.05)\end{array}$ & 0.016 & 0.067 \\
\hline BP systolic, mmHg & $145.7(19.2)$ & $147.7(21.0)$ & $\begin{array}{c}-2.01 \\
(-4.15 \text { to } 0.13)\end{array}$ & 0.066 & $\begin{array}{c}-2.15 \\
(-4.90 \text { to }-0.60)\end{array}$ & 0.127 & $\begin{array}{c}-3.50 \\
(-6.75 \text { to }-0.25)\end{array}$ & 0.035 & 0.024 \\
\hline Cholesterol, mmol/l & $5.2(1.0)$ & $5.0(1.1)$ & $\begin{array}{c}0.21 \\
(0.10 \text { to } 0.32)\end{array}$ & $<0.001$ & $\begin{array}{c}0.14 \\
(-0.002 \text { to } 0.28)\end{array}$ & 0.054 & $\begin{array}{c}0.02 \\
(-0.19 \text { to } 0.24)\end{array}$ & 0.827 & 0.024 \\
\hline Body mass index, $\mathrm{kg} / \mathrm{m}^{2}$ & $29.4(5.5)$ & $30.2(6.9)$ & $\begin{array}{c}-0.82 \\
(-1.45 \text { to }-0.19)\end{array}$ & 0.011 & $\begin{array}{c}-0.33 \\
(-1.12 \text { to } 0.47)\end{array}$ & 0.422 & $\begin{array}{c}-0.42 \\
(-1.41 \text { to } 0.58)\end{array}$ & 0.412 & 0.009 \\
\hline DTSQ & $31.6(5.2)$ & $30.4(5.5)$ & $\begin{array}{c}1.23 \\
(0.65 \text { to } 1.81)\end{array}$ & $<0.001$ & $\begin{array}{c}0.03 \\
(-0.68 \text { to } 0.73)\end{array}$ & 0.939 & $\begin{array}{c}-0.19 \\
(-1.01 \text { to } 0.64)\end{array}$ & 0.660 & 0.037 \\
\hline
\end{tabular}

${ }^{a}$ Adjusted for case-mix differences including sex, age, duration of diabetes, microvascular and macrovascular complications, education, insulin use, and quality of life. ${ }^{b}$ Adjusted for case-mix differences and practice-level clustering. HbA1c = haemoglobin A1c. BP $=$ blood pressure. DTSQ $=$ Diabetes Treatment Satisfaction Questionnaire. ICC = intracluser correlation. 
Table 5. Percentages of patients treated to target.

\begin{tabular}{|c|c|c|c|c|c|c|c|c|c|}
\hline \multirow[b]{2}{*}{ Outcome } & \multirow[b]{2}{*}{$\begin{array}{c}\text { Primary } \\
\text { care }\end{array}$} & \multirow[b]{2}{*}{$\begin{array}{l}\text { Secondary } \\
\text { care }\end{array}$} & \multicolumn{5}{|c|}{ Difference $(95 \%$ Cl) } & \multirow[b]{2}{*}{$P$-value } & \multirow[b]{2}{*}{ ICC } \\
\hline & & & Unadjusted & $P$-value & $\begin{array}{l}\text { Case-mix } \\
\text { adjustment }\end{array}$ & $P$-value & $\begin{array}{l}\text { Full-model } \\
\text { adjustment }^{\mathrm{b}}\end{array}$ & & \\
\hline $\mathrm{HbA} 1 \mathrm{c}<8 \%, \%$ & 82.9 & 65.6 & $\begin{array}{c}0.39 \\
(0.31 \text { to } 0.50)\end{array}$ & $<0.001$ & $\begin{array}{c}0.64 \\
(0.46 \text { to } 0.90)\end{array}$ & 0.009 & $\begin{array}{c}0.63 \\
(0.46 \text { to } 0.87)\end{array}$ & 0.004 & 0.037 \\
\hline $\mathrm{BP}<140 / 85 \mathrm{mmHg}, \%$ & 24.7 & 25.1 & $\begin{array}{c}1.03 \\
\text { (0.80 to } 1.32)\end{array}$ & 0.844 & $\begin{array}{c}1.11 \\
\text { (0.79 to } 1.54)\end{array}$ & 0.551 & $\begin{array}{c}0.94 \\
(0.70 \text { to } 1.27)\end{array}$ & 0.710 & 0.011 \\
\hline $\begin{array}{l}\text { Cholesterol }<5 \mathrm{mmol} / \mathrm{l} \text { or } 6 \mathrm{mmol} / \mathrm{l} \\
\text { for non-smokers without vascular } \\
\text { complications, } \%\end{array}$ & 41.6 & 50.5 & $\begin{array}{c}1.48 \\
\text { (1.19 to } 1.85)\end{array}$ & $<0.001$ & $\begin{array}{c}1.34 \\
\text { (0.999 to } 1.80)\end{array}$ & 0.051 & $\begin{array}{c}1.21 \\
(0.88 \text { to } 1.67)\end{array}$ & 0.239 & 0.016 \\
\hline
\end{tabular}

${ }^{a}$ Adjusted for case-mix differences including sex, age, duration of diabetes, microvascular and macrovascular complications, education, insulin use, and quality of life. ${ }^{b}$ Adjusted for case-mix differences and practice-level clustering. HbA1c = haemoglobin A1c. BP = blood pressure. ICC $=$ intracluser correlation.

complications, and perceived a lower quality of life. These case-mix differences are undoubtedly the result of the Dutch healthcare system, in which primary care physicians are advised to refer their patients with type 2 diabetes only for some welldescribed indications, usually signs of advanced disease. Most differences in outcome measurements between primary and secondary care became non-significant after adjusting for both case-mix differences and clustering. However, mean $\mathrm{HbA} 1 \mathrm{c}$ and systolic blood pressure in primary care remained significantly lower, and more patients demonstrated an $\mathrm{HbA} 1 \mathrm{c}<8 \%$.

\section{Limitations of the study}

This study has some limitations. Firstly, GPs with a particular interest in diabetes may have been selected. However, as approximately half of the primary care physicians in the study region participated, and some of them did not even keep a register of their patients with type 2 diabetes, it can be assumed those selected were not only those paying special attention to diabetes care. Secondly, as the model used by the Quality of Care and Outcomes in Type 2 Diabetes study group was adjusted to the local guidelines, its validity to predict long-term outcomes may have been altered. Since the modifications made in the present study gave rise to even stricter targets, the adjusted model is still able to predict the long-term outcome of diabetes care. Also, a repeated analysis with the original model produced similar results.

Thirdly, baseline measurements in primary and secondary care were performed differently. Therefore, some differences in treatment outcome between general practice and outpatient clinic may be due to differences in data collection. However, as this study only used the most recent data available from the patient records in secondary care, this should not apply. Fourthly, as the present study has been performed in a defined geographic region, it is questionable whether the results of this study can be generalised. The findings of the present study regarding the quality of diabetes care in both general practice and outpatient clinic are in line with those of other studies performed in the Netherlands. ${ }^{15-18}$ Consequently, the results of this study can be considered representative for the quality of diabetes care in the Netherlands.

Finally, the use of a single imputation procedure may have resulted in an underestimation of the standard errors, or $P$-values that were too small. ${ }^{13}$ Because it was not possible to demonstrate a significant difference in the overall quality of diabetes care between general practice and outpatient clinic, the results of the present study are obviously not hampered by the use of a single imputation procedure.

\section{Comparison with existing literature}

The findings of this study are in line with studies performed in different healthcare settings. In both the US and in Italy, differences between specialties became non-significant after adjusting for case-mix differences and physician-level clustering. ${ }^{3,4}$ Control of cardiovascular risk factors in the Italian study was suboptimal, as $65 \%$ of the patients showed total cholesterol and blood pressure levels above target. ${ }^{3}$ These results are in accordance with the present study, as it also found insufficient blood pressure control, and cholesterol levels above target in the majority of participating patients.

A study in 2006 investigating the use of vascular risk-modifying medications for patients with diabetes demonstrated remarkable differences between specialties. ${ }^{19}$ Patients treated in secondary care were more likely to receive ACE inhibitors and ATII antagonists. Differences between study groups remained after adjusting for case mix and clustering. ${ }^{19}$ After taking case mix and physician- 
level clustering into account, the present study was unable to reproduce these results.

\section{Implications for future guidelines and clinical practice}

Using a slightly adjusted version of the original score by the Quality of Care and Outcomes in Type 2 Diabetes study group, this study showed that the overall quality of diabetes care in a single geographic region did not differ significantly between specialties. As patients treated at the outpatient clinic developed more macrovascular and microvascular complications despite their younger age, these patients may have a more severe course of diabetes. One might argue that these patients should be treated more aggressively. In that respect it should be kept in mind that in both care settings, only one-third of the patients showed a summary score $>20$ points, which is related to an important reduction in cardiovascular events. ${ }^{10}$

There is still much room for improvement; treatment should differentiate between patients, not only regarding the setting of their treatment, but also regarding the required intensity of disease management. Future guidelines should take these facts into consideration. The (adapted) summary score can be easily managed, and interpretation is relatively simple. If other studies confirm the results of the original QuED study, the QuED score could be recommended on a large scale.

\section{Funding body}

We are grateful for the non-restricted grant from AGIS Health Insurance Company

\section{Ethical approval}

The medical ethics committee of the University Medical Centre Utrecht approved the protocol of the study and all participants gave informed consent

\section{Competing interests}

The authors have stated that there are none

\section{Acknowledgements}

We wish to thank patients, physicians, and laboratory staff for their participation

\section{Discuss this article}

Contribute and read comments about this article on the Discussion Forum: http://www.rcgp.org.uk/bjgp-discuss

\section{REFERENCES}

1. Baan CA, Poos MJJC. Hoe vaak komt diabetes mellitus voor en hoeveel mensen sterven eraan? [How often does diabetes mellitus occur and how many people are dying because of it?] In: Volksgezondheid Toekomst Verkenning, Nationaal Kompas Volksgezondheid. Gezondheid en ziekte\Ziekten en aandoeningen $\backslash$ Endocriene, voedings- en stofwisselingsziekten en immuniteitsstoornissen $\backslash$ Diabetes mellitus $[$ Health and disease $\backslash D$ iseases and disorderslendocrine, diet-related and metabolic diseases and immunologic impairments\Diabetes mellitus.]. 12-12-2005. Bilthoven: RIVM.

http://www.nationaalkompas.nl (accessed 22 Jan 2008).

2. Baan CA and Wieren $S$ van. Welke zorg gebruiken patiënten en wat zijn de kosten? [What kind of care do patients use and what are the expenses?] In: Volksgezondheid Toekomst Verkenning, Nationaal Kompas Volksgezondheid. Gezondheid en ziekte\Ziekten en aandoeningen $\backslash$ Endocriene, voedings- en stofwisselingsziekten en immuniteitsstoornissen $\backslash$ Diabetes mellitus. [Health and

disease $\backslash$ Diseases and disorderslendocrine, diet-related and metabolic diseases and immunologic impairments $\backslash$ Diabetes mellitus.] 12-12-2005. Bilthoven: RIVM.

http://www.nationaalkompas.nl (accessed 22 Jan 2008).

3. De Berardis G, Pellegrini F, Franciosi M, et al. Quality of care and outcomes in type 2 diabetic patients: a comparison between general practice and diabetes clinics. Diabetes Care 2004; 27(2): 398-406.

4. Greenfield S, Kaplan SH, Kahn R, et al. Profiling care provided by different groups of physicians: effects of patient case-mix (bias) and physician-level clustering on quality assessment results. Ann Intern Med 2002; 136(2): 111-121.

5. Whitford DL, Roberts SH, Griffin S. Sustainability and effectiveness of comprehensive diabetes care to a district population. Diabet Med 2004; 21(11): 1221-1228.

6. Fleming BB, Greenfield S, Engelgau MM, et al. The Diabetes Quality Improvement Project: moving science into health policy to gain an edge on the diabetes epidemic. Diabetes Care 2001; 24(10): 1815-1820.

7. De Berardis G, Pellegrini F, Franciosi M, et al. Quality of diabetes care predicts the development of cardiovascular events: results of the QuED study. Nutr Metab Cardiovasc Dis 2008; 18(1): 57-65.

8. Dolan P. Modeling valuations for EuroQol health states. Med Care 1997; 35(11): 1095-1108.

9. Goddijn $\mathrm{P}$, Bilo $\mathrm{H}$, Meadows $\mathrm{K}$, et al. The validity and reliability of the Diabetes Health Profile (DHP) in NIDDM patients referred for insulin therapy. Qual Life Res 1996; 5(4): 433-442.

10. Brooks R. EuroQol: the current state of play. Health Policy 1996; 37(1): 53-72.

11. Redekop WK, Koopmanschap MA, Stolk RP, et al. Health-related quality of life and treatment satisfaction in Dutch patients with type 2 diabetes. Diabetes Care 2002; 25(3): 458-463.

12. Zaslavsky AM. Statistical issues in reporting quality data: small samples and casemix variation. Int J Qual Health Care 2001; 13(6): 481-488.

13. Donders AR, van der Heijden GJ, Stijnen T, Moons KG. Review: a gentle introduction to imputation of missing values. J Clin Epidemiol 2006; 59(10): 1087-1091.

14. Little RJA. Regression with missing Xs: a review. J Am Stat Assoc 1992; 87: 1227-1237.

15. Cleveringa FG, Gorter KJ, van den Donk M, et al. Task delegation and computerized decision support reduce coronary heart disease risk factors in type 2 diabetes patients in primary care. Diabetes Technol Ther 2007; 9(5): 473-481.

16. Dijkstra RF, Braspenning JC, Huijsmans Z, et al. Patients and nurses determine variation in adherence to guidelines at Dutch hospitals more than internists or settings. Diabet Med 2004 21(6): 586-591

17. Goudswaard AN, Stolk RP, de Valk HW, Rutten GE. Improving glycaemic control in patients with Type 2 diabetes mellitus without insulin therapy. Diabet Med 2003; 20(7): 540-544.

18. Schaars CF, Denig P, Kasje WN, et al. Physician, organizational, and patient factors associated with suboptimal blood pressure management in type 2 diabetic patients in primary care. Diabetes Care 2004; 27(1): 123-128.

19. Shah BR, Hux JE, Laupacis A, et al. Use of vascular riskmodifying medications for diabetic patients differs between physician specialties. Diabet Med 2006; 23(10): 1117-1123. 